\title{
Effectiveness of Teaching Soft Skills to Engineering Students in Moroccan Higher Education
}

\author{
Moustadraf Hind \\ University Mohammed V, Rabat, Morocco
}

\begin{abstract}
Considering the changing educational trends, versatility in teaching methods, the competitiveness of the labour market and the competition for job acquisition, students are left with no choice but to add values to their hard skills with soft skills to exhibit their true potential [18]. Soft skills refer to nontechnical skills such as listening, communication, teamwork, time management, self-management, empathy, integrity, flexibility, emotional intelligence, and related social skills [1]. In recent years, many reforms were implemented by the Moroccan Ministry of Higher Education to encourage the development of soft skills among graduates in order to enhance their employability. For technically based occupations like engineering, soft skills are very important for the application of technical knowledge at work effectively [8]. Thus, this study focuses on developing soft skills in undergraduate engineering students of four Moroccan Universities. This paper discusses the importance of soft skills for students, the type of pedagogical methods initiated by varied educational institutions; their relevance and their impact in developing soft skills and benefits to students. Therefore, this paper proposes measures to develop and improve the implementation of soft skills within universities which will lead to heightened interpersonal and social skills furthermore increasing employability.
\end{abstract}

\section{Introduction}

"Education is the lifeblood of the country's new development model" which means that, in order to transform Morocco into a developed nation, it is necessary to improve education performance and teaching quality (Morocco's Education Minister, 2019).

For that purpose, the Ministry of Higher Education developed many reforms to improve the quality of university education in the kingdom by integrating soft skills in the curriculum to enhance graduate employability.

Essentially, soft skills refer to personalities, attributes, qualities and personal behaviour of individuals. Soft skills include certain abilities such as communication, problem-solving, self-motivation, decision-making, and time management skills [7]. Additionally, it is said that hard skills are the academic skills, experience and level of expertise

that is generally described in a resume, and the principles, methods, procedures and techniques needed for performing jobs. Contrarily, soft skills are sought out behaviours and characteristics that employees demonstrate unconsciously and routinely on the job [18].

Researchers have reported that recruiters may prioritize a job candidate with soft skills over someone with technical skills [13]. Most employers are likely to hire, retain and promote persons who are dependable, resourceful, ethical, have effective communication, self-directed, willing to work and learn, and have a positive attitude [18].

Consequently, there is now more pressure on academic institutions to enhance the soft skills of their students. The present study tries to bring awareness to the importance of soft skills by examining the type of pedagogical methods of implementing soft skills within Public and Private Moroccan engineering universities. This research will further examine the relevance, impact and benefit that soft skills can have on students as well as the teaching methods to reinforce students acquisition.

We are therefore interested in analysing soft skills development within Moroccan higher education by answering the following questions:

- $\quad$ To what extent do the pedagogical methods implemented in Moroccan engineering universities allow soft skills acquisition?

- What are the most important soft skills for engineering students?

- What are the benefits of soft skills development to engineering students?

- What is the most suitable environment to acquire soft skills?

- Who is the most resourceful person to successfully implement soft skills within a higher education environment?

- What measures should be undertaken by the university to enable the acquisition of soft skills?

This article proposes to answer these problems by carrying out a methodological analysis which will lead us to address the following three parts in turn:

The first part will be the subject of a brief overview on the literature review which focuses on the definition of soft skills. 
The second part will be devoted to the exposure of the methodology and the population interviewed for the field phase. Let us simply point out that we opted for a qualitative approach to research, in particular by examining students' perceptions regarding the importance of soft skills and analysing the teaching practices adopted by Moroccan universities through semi-structured interviews. The third part will be dedicated to discuss the results of the current study.

\section{Literature Review}

The definition of 'soft skills' widely ranges from, life skills [19], twenty-first century skills [10], "transversal skills", "soft skills" [3], employability skills [2], generic competences as well as key competencies for a successful life, a well-functioning society [12] and lifelong learning [4]. These skills such as communication skills, analytical, critical and problem-solving skills, lifelong learning ability, entrepreneurship and management skills are the ones that employers value as important skills for potential employees to possess [8]. For this reason, all graduates should master and acquire these skills regardless of their field of study. Engineering programs are often criticized for overemphasizing technical skills while giving insufficient attention to nontechnical skills [6]. However, engineering graduates like any other graduate, should have both transversal skills and technical skills in order to have opportune access to the labour market.

Examining the required engineering skills and attributes for engineering graduates at various accrediting institutions and countries (USA, UK, EU, AUS, and Japan), Zaharim et al. [20] has shown that many of the common employability skills for engineers consist of nontechnical skills, such as communication skills, leadership, teamwork, lifelong learning, professionalism, and decision-making skills.

For example communication skills include oral communication with managers and peers, presentation skills, business writing skills, and crosscultural communication abilities. All of these areas can be tackled at the undergraduate level if they are well integrated into engineering program curriculum [11]. Concerning management and leadership skills, they are essential even for technical personnel who perform administrative duties in carrying out their daily functions. They are even more essential for engineers who assume managerial positions later in their careers. Shipper and Dillard [15] highlight that engineers' transition from the technical to the management path can encounter many difficulties, one of which is derailment. Derailment can be described as not meeting management expectations mainly as a result of a lack of management skills.
The empirical study presented in this paper adopted the list of soft skills defined and extensively described by the ModEs European Project [9] (see Table 1).

Table 1. List of the 20 Soft Skills Utilized in the Study [9] [16] [17]

\begin{tabular}{|c|c|}
\hline Category & Skill \\
\hline Personal & $\begin{array}{l}\text { 1. Being Committed to Work - make } \\
\text { a commitment to the organisation and } \\
\text { understand its specific characteristics } \\
\text { 2. Being Professionally Ethical - take } \\
\text { actions while bearing in mind the } \\
\text { principles and ethics of the profession } \\
\text { in daily activities } \\
\text { 3.Being Tolerant to Stress - show } \\
\text { endurance in complicated or stressful } \\
\text { situations } \\
\text { 4.Creativity/Innovation Skills - } \\
\text { contribute new ideas to develop } \\
\text { improvements in the products or } \\
\text { services of the organisation as well as } \\
\text { in the activities performed in the job } \\
\text { 5. Learning Skills - provide a self- } \\
\text { assessment of necessary knowledge } \\
\text { (theoretical or practical) and take } \\
\text { measures to acquire and implement this } \\
\text { knowledge } \\
\text { 6. Life Balance Skills - manage } \\
\text { successfully the frequent conflicts } \\
\text { between life and work } \\
\text { 7. Self-Awareness Skills - grasp our } \\
\text { real weaknesses and strengths }\end{array}$ \\
\hline Social & $\begin{array}{l}\text { 8. Communication Skills }- \text { transmit } \\
\text { ideas, information and opinions clearly } \\
\text { and convincingly, both verbally and in } \\
\text { writing, while listening } \\
\text { 9. Conflict Management and } \\
\text { Negotiation Skills - conciliate different } \\
\text { opinions to reach an agreement that } \\
\text { satisfies everyone } \\
\text { 10. Contact Network Skills - develop, } \\
\text { maintain, and foster contacts } \\
\text { 11. Culture Adaptability Skills - } \\
\text { carry out managerial } \\
\text { entrepreneurial and } \\
\text { multicultural environments } \\
\text { 12. Leadership Skills - motivate and } \\
\text { guide others to get them to contribute } \\
\text { effectively } \\
\text { 13. Team-Work Skills - to build } \\
\text { relationships based on participation and } \\
\text { cooperation with other people }\end{array}$ \\
\hline $\begin{array}{l}\text { Methodolo- } \\
\text { gical }\end{array}$ & $\begin{array}{l}\text { 14. Adaptability to Change Skills - } \\
\text { redirect the course of action to meet } \\
\text { goals in a new situation } \\
\text { 15. Analysis Skills - draw conclusions }\end{array}$ \\
\hline
\end{tabular}




\begin{tabular}{|l|l|}
\hline and forecasts for the future by acquiring \\
relevant information from different \\
sources \\
16. Continuous Improvement Skills - \\
perform the activities, duties and \\
responsibilities inherent to the job \\
under quality standards and strive for \\
excellence \\
17. Customer/User Orientation Skills \\
- identify, understand and satisfy \\
efficiently the needs of customers \\
18. Decision Making Skills - make the \\
decisions necessary to achieve \\
objectives quickly and proactively \\
19. Management Skills - set goals and \\
priorities through the selection and \\
distribution of tasks and resources \\
20. Results Orientation Skills - make \\
organisational efforts profitable while \\
having always in mind the goals \\
pursued
\end{tabular}

\section{Methodology}

The main purpose of this paper is to investigate students' perceptions of the importance of soft skills. A questionnaire was used for data collection and 255 undergraduate engineering students from four universities in Morocco participated in this study.

The students were invited to participate in our study through the lecturers and answered our questions via different distance learning tools: Moodle, Microsoft teams, zoom, and skype.

It should be noted that the study was conducted in French-speaking Moroccan universities, which is why we translated the verbatim from French to English for the purposes of this study.

The questionnaire consisted of multiple-answer multiple choice questions and open-ended questions to solicit their opinions and responses especially towards the courses, projects and activities that have encouraged their acquisition of soft skills. Rather than using software-based methods, we opted to analyze the open-ended questions manually using an inductive thematic analysis known as the classic tool for the study of opinions and perceptions.

It serves to identify the themes and categories present in a corpus and then analyze them. It is a subjective approach that aims to reformulate, interpret and theorize phenomena [5]. Thus, through a horizontal approach, we have identified in the various interviews of the corpus recurring themes and categories and we have grouped them together by relationships and typologies.

\section{Findings}

The main results of this study are presented in the following sections.

\subsection{Awareness of soft skills}

The participating students were asked what soft skills, in their opinion, are essential for engineering graduates. Based on a literature review, a list of 20 skills was developed.

The top five soft skills, as identified by the students, were team-work skills, communication skills, self-awareness skills, tolerance to stress and creativity/innovation (see Table 2).

On the contrary, Life Balance Skills, Customer/User Orientation Skills, Culture Adaptability Skills and Conflict Management and Negotiation Skills are ranked of lowest importance. These skills may not be as important as the previously ranked skills because they are not obviously linked to soft skills.

Table 2. The Most Important Soft Skills for Engineering Graduates (Multiple Responses)

\begin{tabular}{|c|c|c|}
\hline Ranking & Soft skills & $\begin{array}{c}\text { Frequency } \\
(n=255)\end{array}$ \\
\hline $\mathbf{1}$ & Team work skills & 248 \\
\hline 2 & Communication skills & 246 \\
\hline 3 & Self-Awareness Skills & 221 \\
\hline 4 & Being Tolerant to Stress & 218 \\
\hline 5 & Creativity/Innovation Skills & 205 \\
\hline 6 & Results Orientation Skills & 189 \\
\hline 7 & Leadership Skills & 175 \\
\hline 8 & Contact Network Skills & 151 \\
\hline 9 & Management Skills & 149 \\
\hline 10 & Adaptability to Change Skills & 95 \\
\hline 11 & Analysis Skills & 87 \\
\hline 12 & Continuous Improvement Skills & 85 \\
\hline 13 & Being Committed to Work & 42 \\
\hline 14 & Being Professionally Ethical & 39 \\
\hline 15 & Learning Skills & 18 \\
\hline 16 & Decision Making Skills & 9 \\
\hline 17 & $\begin{array}{l}\text { Conflict Management and } \\
\text { Negotiation Skills }\end{array}$ & 2 \\
\hline 17 & Culture Adaptability Skills & 2 \\
\hline 18 & $\begin{array}{l}\text { Customer/User Orientation } \\
\text { Skills }\end{array}$ & 1 \\
\hline 18 & Life Balance Skills & 1 \\
\hline
\end{tabular}




\subsection{Benefits of Soft Skills Development}

According to a student, "the development of soft skills is useful for my engineering career, and these kinds of skills are in high demand" (Student subject). "From a young age we were led to take mainly theoretical courses, which is certainly beneficial for us in order to develop our intelligence and resonance. However this does not teach us the art of communication and teamwork, as well as many other qualities required to improve our professional and personal situation" (Student Subject).

Students participating in this study were asked about the benefits of soft skills development to engineering students. The majority of students mentioned that an increase of compatibility with people is the most important benefit of soft skills acquisition which leads to a" better integration and understanding of the work environment" (Student subject). According to another student: "Softs skills are useful for managing conflicts and problems with our colleagues in the workplace". Table 3 shows the benefits of soft skills development in students. Figure 1 provides the results obtained from the Word frequency counts when asking students benefits of Soft Skills, the most used words are Work and team which reflects the perceived motivation behind Soft Skills acquisition.

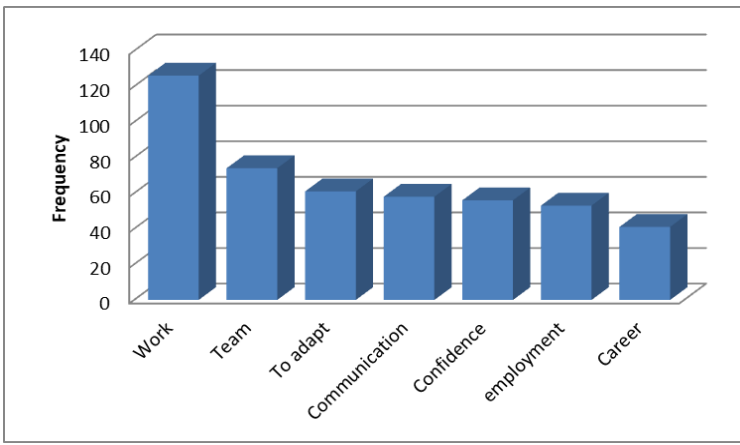

Figure 1. Graphic Representation of the 7 Most Frequently Used Words

Table 3. Benefits of Soft Skills Development $(\mathrm{n}=255)$

\subsection{The Most Suitable Environment to Acquire Soft Skills}

In response to a question on what is the best environment and resourceful person who is able to help students in developing soft skills, the student's opinions were divergent (see Table 4). Most engineering students were of the view that the university professors and lecturers are the best resource persons for achieving the above objective. "I think that the best resource persons who can help me develop my soft-skills are my university professors and I also think that the most suitable environment is the classroom" (student subject). Regarding the subjects enabling the acquisition of these competences, the students insisted on the following courses: "the main persons who can help us develop softs skills are: professor of communication and the professor of business organization." (Student subject). Whereas others argue that these skills can rather be developed within the company with tutors and internship mentors. Being helped by personal coaches can help students deal with new situations that push them out of their comfort zone and deal with stage fright and their lack of confidence. Few students think that we can develop soft skills by ourselves; a student says that "a few simulations in front of the mirror are enough and the trick is done, we just need motivation" (Student Subject). Another student report "I think you don't necessarily need others to develop softskills, just believe in yourself and self-study is the best technique to adopt" (Student Subject)

Table 4: The Most Resourceful Person to Successfully Implement Soft Skills Within a Higher Education Environment (Multiple Responses)

\begin{tabular}{|c|l|c|}
\hline Ranking & \multicolumn{1}{|c|}{ Soft skills } & $\begin{array}{c}\text { Frequency } \\
(\mathbf{n = 2 5 5})\end{array}$ \\
\hline $\mathbf{1}$ & Professors/Lecturers & 186 \\
\hline $\mathbf{2}$ & Internship Tutor/Mentor & 171 \\
\hline $\mathbf{3}$ & Personal development coach & 129 \\
\hline $\mathbf{4}$ & Ourselves & 85 \\
\hline $\mathbf{5}$ & $\begin{array}{l}\text { Experts and Experienced } \\
\text { Engineers }\end{array}$ \\
\hline $\mathbf{6}$ & Parents and family \\
\hline \\
4.4. The Most Effective Pedagogical Methods \\
for Soft Skills Development
\end{tabular}

Regarding the contribution of teaching methods to the acquisition of soft skills, the results of the study show that graduates reported having acquired more soft skills in more active teaching models, based in 
particular on group work, internship and problem solving method and far from the conventional academic model (see Table 5).

Table 5: The Most Effective Teaching Methods for Developing Soft Skills (Multiple Responses)

\begin{tabular}{|c|l|c|}
\hline Ranking & \multicolumn{1}{|c|}{ Soft skills } & $\begin{array}{c}\text { Frequency } \\
(\mathbf{n = 2 5 5})\end{array}$ \\
\hline $\mathbf{1}$ & Group work & 181 \\
\hline $\mathbf{2}$ & Internship & 164 \\
\hline $\mathbf{3}$ & Problem Solving Method & 139 \\
\hline $\mathbf{4}$ & Role playing & 120 \\
\hline $\mathbf{5}$ & Case study & 90 \\
\hline $\mathbf{6}$ & flipped classroom & 70 \\
\hline $\mathbf{7}$ & Lectures & 54 \\
\hline $\mathbf{8}$ & Project based learning & 32 \\
\hline
\end{tabular}

\subsection{The Effectiveness of the Pedagogical Methods Implemented in Moroccan Engineering Universities}

To find out what they think of the teaching methods adopted in the context of their academic career and to know further about these interactive and effective teaching methods, we asked them the following question: "Do you think your training promotes the acquisition of soft skills? Cite examples of activities that helped you develop one or more soft skills mentioned in the first question." The majority of engineering students believe that their academic training promotes the acquisition of soft skills. "All our professors insist on teamwork, whether for projects, internships or even during oral presentations" (student subject). A student subject stated that his machine maintenance work placement with the DANONE plant in Sale was not only beneficial for his technical skills but also to improve his analytical thinking skills, organizing, planning skills and communication skills with co-workers (Student Subject). Another student insisted on workshops as a means of developing soft skills: "The robotics projects organized by the university allow me to develop several transversal skills, such as strengthening my team spirit, and developing my creativity especially during the sessions of computerassisted mechanical design" (student subject).

According to several students, oral presentations in class also help to develop soft skills and more precisely communicative skills; "oral presentations in pairs allowed us to improve our team spirit, our ability to analyze, solve problems and acquire the ability to work under pressure and manage time" (student subject).
Whereas for others "our training unfortunately does not promote the acquisition of soft-skills since we focus only on lectures neglecting the importance of parallel activities" (student subject). These students underline the importance of extracurricular activities to develop this type of skills. "It's rather outside of class that we could develop them. I had the opportunity and the chance more than a year ago now to participate as a benevolent guide to the event "the night of the philosophers" where my role was to direct participants to the conferences they wished to attend and answer their different questions. It was an enriching experience that helped me a lot to develop my communication with others which is not my first quality." (student subject).

"From my personal perspective, my participation in the forums has had a huge impact on my way of being. Of a calm and reserved nature, it helped me to dare to speak, to go towards the people. Indirectly, my self-confidence has improved and I begin to give my opinion without being afraid of judgment or underestimating my ability to solve problems. I even learned to listen to others which allowed me to improve the efficiency of group work and to perfect my results" (student subject).

\subsection{Measures to Improve Soft Skills Development}

The students suggested several measures to be undertaken by universities in order to improve the acquisition of soft skills. Almost $50 \%$ of the students recommended that more internships should be incorporated into the pedagogical curriculum of the university to help students discover the reality of the labor market (see Table 6). Two other measures suggested by around $40 \%$ of students were to organize visits to companies and incorporate soft skills into the curriculum.

Table 6: Measures to be Undertaken by Universities for Effective Soft Skills Development

\begin{tabular}{|c|l|c|}
\hline & \multicolumn{1}{|c|}{ Benefits } & Frequency \\
\hline $\mathbf{1}$ & Increase internship opportunities & 126 \\
\hline $\mathbf{2}$ & Organize visits to companies & 97 \\
\hline $\mathbf{3}$ & $\begin{array}{l}\text { Incorporate soft skills into the } \\
\text { curriculum }\end{array}$ & 89 \\
\hline $\mathbf{4}$ & Organize more workshops & 41 \\
\hline $\mathbf{5}$ & Organize round tables & 34 \\
\hline
\end{tabular}




\section{Discussion}

This paper contributes in several ways to the discussion towards the increased relevance of soft skills within higher education in engineering studies. The importance of soft skills identified amongst students confirms that the current economic situation and the technological development led to a higher emphasis on graduates' ability to communicate effectively with managers, co-workers, subordinates and others in general, on their ability to build positive relationships with multiple teams, on the ability to react and interact in the work place on being self-confident, on their capacity to adapt and being integrated within the company. Therefore, developing soft skills in students is an undeniable lever that will allow them to better understand professional and entrepreneurial life.

In particular, we focused on the students' perception in order to better understand and gather their needs, difficulties and suggestions for improving the development of soft skills in their university curriculum. Students were asked to assess the pedagogical methods implemented by their university and to suggest the best methods allowing a better soft skill acquisition. It emerged from the results that interactive teaching methods based on group work, internship or problem-solving projects encourage students to play an active role in teaching by awakening their curiosity and creativity. These learning methods develop critical thinking, analytical skills, social intelligence and communicative skills of students regardless of their training. These findings are in line with Wats and Wats [18] study on developing soft skills in students. The authors highlight the fact that the five most effective methods were experiential learning, role-playing, team work Methods, case studies and extra-curricular activities.

In order to accompany the engineering graduates in their training process and in order to complete and sharpen their profile, the activities oriented soft skills constitute a differentiating factor and a strong point of future engineers. Along the same lines, the results of this study show that the main players/stakeholders to be involved in soft skills acquisition are: Students/graduates, companies and universities.

Another related finding was that a majority of the students expressed the opinion that the university should encourage and give the student the opportunity to do more internships and professional visits to companies. Probably this measure is preferred because it gives students the opportunity to observe and evaluate other professionals in particular contexts, hence, they could apply these skills in a specific situation. It is equally important that soft skills training be embedded in technical courses.

\section{Conclusion}

The aim of the present research was to examine the evolving importance of soft skills in a competitive environment, as well as to investigate the perceptions of students concerning the importance of acquiring soft skills. Specifically, this study focused on engineering students in Moroccan Universities. In this investigation, the aim was to assess student subject perspectives of the importance of soft skills, implementation of soft skills in University settings, and the measures that should be taken by universities to better enable the acquisition of soft skills.

Previous research has established that 'success as an engineer requires more than simply strong technical capabilities" and "therefore, they need soft skills to complement technical skills"[8]. This study has confirmed that engineering students are acutely aware of the importance of soft skills to accompany their already acquired technical skills, this further complements the findings of earlier studies. Specifically, engineering students ranked team work skills and communication skills as equally comparable to that of technical skills. This evidence from this study suggests that because students are frequently asked to work in group settings, they therefore have the unconscious perception that these two transversal skills are indispensable for them. Contrarily, results of this study indicated that Customer/ User Orientation Skills and Life Balance Skills are the least important soft skills for engineering students (see Table 2). This can be explained by the assumption that students are not yet aware of the relevance of life balance skills, and especially engineering students are not aware of customer/ user orientation skills because they see these skills as more applicable in a business environment. However, the pressure that can accumulate from future employers and work conditions can prove that these skills are necessary soft skills for their personal and professional development. Overall, all soft skills should be taken into consideration within a student's academic career, even for technically based occupations.

One of the more significant findings to emerge from this study is that within the benefits of soft skills development, students listed personal benefits before professional benefits. Specifically, within the findings students ranked an increase of compatibility with people and build your self-esteem over enhance your employability (see Table 3 ). This suggests that students believe that getting along with others can lead to a higher chance of employment. This can be linked to previous results from the Most Important Soft Skills for Engineering Graduates (see Table 2) where students ranked Team Work skills and Communication Skills as the most important. 
The research has also shown that interactive teaching methods based on group work, internship or problem-solving projects encourage students to play an active role in teaching by arousing their curiosity and creativity. These learning methods develop critical thinking, analytical skills, social intelligence and communicative skills of students especially for Modern engineers who need to reinvent themselves to meet the challenges confronting them in the $21 \mathrm{st}$ century; thus, they have to be willing to learn, unlearn and then relearn in order to keep abreast of the latest developments in this ever-changing society [8].

Therefore, there are a number of important changes which need to be taken by the two major players in student life, namely companies and universities. These two entities need to work together not only to increase students' awareness of the importance of soft skills but also to steer them toward professional success by providing them with the opportunity to hone their essential skills in order to continuously adapt to the changing labor market and improve their employability.

\section{References}

[1] Andrews, J., and H. Higson. 2008. "Graduate Employability,'Soft Skills' Versus 'Hard' Business Knowledge: A European Study." Higher Education in Europe 33 (4): 411-422.

[2] Cotton K. (1995) Developing employability skills. Portland, OR: North West Regional Educational Laboratory

[3] Davis, D.C., and B. Woodward. (2006). "An Analysis of Skills Required of Graduates of an Information Systems Program", Information Technology, Learning, and Performance Journal, Vol.24, №2, pp. 1-10.

[4] EU (European Union). 2006. Key Competences for Life Long Learning, Recommendation the European Parliament and the Council of 18th December 2006. Official Journal of the European Union (2006/962/EC), L394/10-18. http://eur-lex. europa.eu/legalcontent/EN/TXT/?uri = celex:32006H0962 (Access Date: 24-10-2014).

[5] Gavard-Perret, M.L., D. Gotteland, C. Haon and A. Jolibert, Méthodologie de la recherche, Pearson Education France, Paris, 2008.

[6] Gilleard, J., and Gilleard, J. D. (2002). "Developing cross-cultural communication skills." J. Prof. Issues Eng. Educ. $\quad$ Pract., 10.1061/(ASCE) 10523928(2002)128:4(187), pp. 187-200.

[7] Gupta, Y. (2009). Building a better business student. BizEd, 9(6), pp. 62-63.

[8] Hairuzila, I. (2009). "Challenges in the integration of soft skills in teaching technical courses: Lecturers' perspectives". Asian Journal of University Education, 5(2), pp. 67-81.

[9] Haselberger, D., Oberheumer, P., Perez E., Cinque, M. and Capasso, D. (2012). "Mediating Soft Skills at Higher Education Institutions", Handbook of ModEs Project, Life Long Learning Programme.

[10] Moore, T., and J. Morton. 2017. "The Myth of Job Readiness? Written Communication, Employability, and the 'Skills Gap' in Higher Education." Studies in Higher Education 42 (3), pp. 1-19.

[11] Norback, J. S., Leeds, E. M., and Forehand, G. A. (2009)."Engineering communication - Executive perspectives on the necessary skills for students." Int. J. Modern Eng., 10(1), 11-19.

[12] OECD. 2012. Better Skills, Better Jobs, Better Lives: A Strategic Approach to Skills Policies. Paris: OECD Publishing.

[13] Robles, M. M. (2012). "Executive Perceptions of the Top 10 Soft Skills Needed in Today's Workplace". Business Communication Quarterly, 75 (4), pp. 453-465.

[14] Shaheen, M., Zhang, L., Shen, T., Siti, R. (2012). "Importance of Soft Skills for Education and Career Success". International Journal for Cross-Disciplinary Subjects in Education (IJCDSE), 2(2), pp. 1036-1042.

[15] Shipper, F., and Dillard, J. E. (2000). "A study of impending derailment and recovery of middle managers across career stages." Hum. Resour. Manage., 39(4), pp. $331-345$.

[16] Succi, C. (2018). "Are You Ready to Find a Job? Ranking of a List of Soft Skills to Enhance Graduates'Employability". International Journal of Human Resources Management and Development.

[17] Succi, C. and Canovi, M. (2019). "Soft skills to enhance graduate employability: comparing students and employers' perceptions". Studies in Higher Education,45, pp.1834-1847.

[18] Wats, M., and Wats, R.K. (2009). "Developing soft skills in students". The International Journal of Learning, 15(12), pp.1-10.

[19] WHO. 1993. "Life Skills Education in Schools." Skills for Life 1 . Genève.

[20] Zaharim, A., Omar, M. Z., Yusoff, Y. M., Muhamad, N., Mohamed, A., and Mustapha, R. (2010). "Practical framework of employability skills for engineering graduate in Malaysia." Proc., Education Engineering (EDUCON), 2010 IEEE, IEEE, Piscataway, NJ, pp. 921-927. 